\title{
Inflation and Dividend Behavior of Pakistani Firms: An Empirical Investigation Using ARDL
}

\author{
Abdul Ghafoor ${ }^{1}$, Muhammad Asif Khan ${ }^{2}$, Syed Asim $\operatorname{Shah}^{1}$ \& Habib Hussain Khan ${ }^{3}$ \\ ${ }^{1}$ National University of Modern Languages, Islamabad, Pakistan \\ ${ }^{2}$ Allama Iqbal Open University, Islamabad, Pakistan \\ ${ }^{3}$ University of Malaya, Malysia \\ Correspondence: Abdul Ghafoor, National University of Modern Languages, Islamabad, Pakistan. E-mail: \\ a.ghafoor44@hotmail.com
}

Received: July 14, 2014

Accepted: July 28, $2014 \quad$ Online Published: August 22, 2014

doi:10.5539/ijbm.v9n9p86

URL: http://dx.doi.org/10.5539/ijbm.v9n9p86

\begin{abstract}
The purpose of this study is to examine the dividends behavior of Pakistani firms by taking a macroeconomic perspective. In doing that inflation and real growth are also considered. The paper examines the relationship between dividend yield, return on equity, real growth and inflation in the Pakistan by applying ARDL approach which is used to examine the relationship in the long run. Moreover, VECM is also applied to capture the short run impact. Results of ARDL revealed a positive relationship between inflation and dividend payments, which can be interpreted in two ways. First, inflation affects revenues and variable cost not the fixed cost; it simply increases the nominal value of corporate earnings and therefore dividend payouts, and second is that managers may try to pursue a dividend policy, which is considered to be optimal, believing that there is a desirable level of real dividend income to be paid to their investors. The results of ARDL approach show that inflation, in long term as well as in short run have positive relationship with dividends while return on equity and real growth rates showed insignificant relationship with dividend yield in both long and short run. The estimated equation remains stable over the period of study as indicated by CUSUM and CUSUMQ stability tests. This study is helpful for various investors in deciding for investment when they have fear of considerable acceleration of inflationary pressure. For example they can protect themselves against accelerating inflation rates when buying the stocks. While formulating an optimal dividend policy of the firm, managers should carefully examine the inflationary environment.
\end{abstract}

Keywords: inflation, dividends, ARDL approach

\section{Introduction}

The financial policies of a country affect the financial performances of the companies and their future sustainable development and growth. The financial decisions of the companies can be influenced by several internal and external factors or so called determinants of financial policies. In fact internal factors and their impacts can be managed by a company, at the same time macroeconomic factors cannot be controlled by the managers. However both types of determinants have a significant influence on the corporate financial decisions. And the knowledge about the level, direction and power of their impact support companies to make effective decisions for the purpose of financial stability and sustainable growth. Returns of the investors depend upon the performance of the companies and performance of the companies in turn depends upon the controllable and uncontrollable factors in the economy. Investors place their investment decision on the expected performance of the companies.

Investor's returns can take the forms of dividends and capital gains. According to clientele effect, an individual investor constructs his portfolios by having a mixture of capital gains and dividends. Some investors give more weights to capital gains and some others to dividends depending upon their short term and long term investment needs. According to Fischer Hypothesis (1930), there exists a positive relationship between inflation and capital gains of investors. Various studies conducted by Schwert and Fama (1977), Bodie (1976), Geske and Roll (1983), Gultekin (1983), Amihud(1996), Kolari and Anari (2001) and Luintel and Paudyal (2006) have focused on the relationship between inflation and capital gain of investors which is one form of investor's return. Only few 
studies, for example, Basse (2009) and Basse and Reddemann (2011) have focused on the relationship between inflation and dividends which is the another important portion of investor's return. This study therefore attempts to explain returns of the investors in the form of dividends from a macroeconomic perspective using inflation and real growth rates in Pakistani economy.

There are many macroeconomic factors which may affect the overall economy. Inflation is of prime focus because it affects the overall economy and consequently on companies operating in particular environment. In an environment of inflation, companies cannot think about their future, manufacturers keep on increasing prices, investments decline and financial institutions suffer. According to Schwert (1981), stock market showed a negative reaction to the announcement of unexpected inflation although the magnitude of reaction was not so great. Modigliani and Cohn (1979) found that investors hesitate to invest in an environment of inflation because they get uncertain about future cash flows. In a study conducted by Greg (2011), results revealed that inflation uncertainties affect the investment in a way that in periods of high inflation, there is less investment in fixed assets which distort mostly the investment decisions of poor entrepreneurs. They don't include long term securities in their portfolios and invest in short term securities or secure securities. Accroding to Bradt and Wang (2003), investors get risk averse in their behaviors by requiring higher inflation adjusted returns.

According to Miller and Modigliani (1961), in a perfect capital market and in absence of taxes, dividend payments are irrelevant because it does not affect the value of the firm. So there exists no optimal dividend policy as changes in dividends have no economic implication. According to Black (1976), dividends are puzzle like more we look into this more it gets confusing.

But Agency Theory by Jensen and Meckling (1979) provides justification for the payments of dividends as these are used as a signal by the management to inform the shareholders for the revised expectations of earnings. It is a tool to overcome the information asymmetry. Various studies conducted on the importance of dividends produced mixed empirical results. According to Allen and Michaely (1995), much work is left to be done on dividends. Similarly, Collins, Saxena, and Wansley (1996) argued that dividend policy is yet an unresolved issue. For this, dividend behavior is reviewed extensively by various researchers and in different points of time and in different contexts. Most of the available research papers, address only firm specific determinants of dividend policy. Results of these studies found to be mixed. Reasons for these mixed empirical findings can be due to usual negligence of macroeconomic factors. Do macroeconomic variables influence dividend decisions of Pakistani firms? The need to address this question is the prime motive of this study. Mohsin and Ashraf (2011) in Pakistan and Pandey and Bhatt (2007) in India respectively studied the monetary policy restrictions as macroeconomic factor on dividend decision of companies. Main purpose of this study is to analyze the dividend policy from macroeconomic perspective using inflation and GDP growth rate.

Study also takes corporate earnings as these are the main drivers of dividends. An increase in earnings may lead to increase in dividends. So, generally there is found a positive relationship between earnings and dividends. Similarly, real economic growth is the main driver of earnings. An increase in real economic activity increases the corporate earnings of different sectors operating in the economy leading to higher earnings which may ultimately lead to higher dividend payments.

\section{Literature Review}

Investors required returns can take various forms, for example some investors prefer dividends while other prefers capital gains. Dividends are payments that organizations pay to its shareholders out of earnings of firms and are considered as returns to shareholders in providing finances to company. These can be paid in the form of cash dividends, stocks dividends and liquidating dividends. Black (1976) wrote about dividend policy as dividend puzzle that more we look at this puzzle more it gets confusing and question of optimal dividend policy with why managers hesitate to cut dividend is an unanswerable yet.

There are various theories about dividend policy, but the work of Miller and Modigliani (1961) dividend irrelevance theory put the foundation of an unending debate among the researchers. In their seminal work, Miller and Modigliani demonstrated that dividend is irrelevant phenomenon whether companies pay it or not; it does not affect shareholders wealth. According to this theory, dividend is irrelevant under certain assumptions. Authors argued that it does not matter for investors whether they receive dividend streams or capital gains; their overall value is not changed. Any dividend paid to shareholders is balanced by issuing more shares such that gains of investors in the form of cash dividends are offset by decline in capital gains. Many researchers supported the irrelevance hypothesis. For example Black and Scholes (1974) working on effect of dividend yield and dividend policy on common stock prices and returns found that stock prices are not influenced by high yield payout or low yield payout. Both high yield and low yield stocks had same expected returns in their study. 
Similarly work of Miller and Scholes (1982), Bernstein (1996) and Kaleem and Salahuddin (2006) also supported MM irrelevance.

Besides of the support of Miller and Modigliani, different researchers, for example, Baker et al. (1985), Partington (1985), Siddiqui (1995) and Baker and Powell (1999) rejected this hypothesis showing dividends as a significant factor when investors make investment decisions in stocks. Stocks are considered to be hedge against inflation. Various studies are conducted to empirically prove this assumption. Discussion remained only on one aspect of the return that is capital gain. And literature on it starts from the work of Fischer (1930), who for the first time studied the relationship among real returns, nominal returns and inflation. He presented his theory known as "Fisher Hypothesis". Applying Fisher Hypothesis to stocks, researchers argue that stocks can act as effective hedge against inflation. Researchers explain this mechanism that as general price level increase in the economy; it causes an increase in nominal value of shares and thus inflation does not affect the real value of stocks.

As stocks are considered to be claims on real capital of the companies, these are taken as an effective hedge against inflation to many investors. Financial analysts need to address corporate earnings while examining the relationship between inflation and equity market. In an inflationary macroeconomic environment, firms are able to increase their revenues. Thus with the growth of inflation, nominal earnings should also grow, enabling management to have stabilized real earnings. These general arguments can help investor to consider such relationship of stock returns and inflation.

But empirical evidences are contrary to the explanation. Fischer hypothesis does not move straight and results are contradictory to his proposition. For example, Geske and Roll (1983), Gultekin, (1983), Amihud (1996) and Engsted and Tanggaard (2002) found negative association between equity returns and inflation. This negative association of inflation and equity returns is also empirically examined by Fama and Schwert (1977)). Fama (1981) proposed that in order to estimate the returns, income growth should also be considered. Fischer hypothesis cannot be rejected if income growth is included in the function. It is the proxy hypothesis that explains the negative association of equity returns and inflation. These results have been examined by Reilly (1997).

Some studies found a long run positive association of dividend and stocks, these findings confirmed that stocks are inflation hedged. For example, Rao and Bhole (1990) reported a positive association of equity returns and inflation in India. Similarly results of several other studies, Kolari and Anari (2001); Luintel and Paudyal (2006) also confirmed positive relationship in their study. Moreover, Campbell and Shiller (1988) examined dual association of inflation and equity returns. At one end, inflation creates uncertainties compelling investors to require more returns and hence high discount rates leading to low returns, because returns are present value of all expected cash flow. On the other end, inflation magnifies the revenues leading to higher expected returns. Over all net effect remains positive in long run.

To many investors, the negative association of equity returns and inflation is a puzzle. For example a negative association of inflation announcements to the equity market is found by Schwert (1981). He named the inverse association of stock returns and inflation as "inflation-equity returns mystery. Feldstein (1982) claimed that cause of inverse association of stock returns and inflation are the tax laws. Additionally, price system gets distorted due to high inflation and slows down the economic growth, Barro (1996). According to Fama (1981), the inverse association of inflation and stock returns exists because of the proxy hypothesis. Proxy hypothesis states that the negative association of inflation and stock returns is the presence of two other relationships. One is a positive association of future economic growth and equity returns, the second is a negative association of future economic growth and inflation.

One can observe two trends in different studies, for example, Campbell and Shiller (1988) confirmed that two trends are presents; it is also confirmed by the studies of Schotman and Schweitzer (2000) and Basse (2009). It is due to two reasons, one is that firms' revenues increase in nominal terms owing to inflation, this leads to increased expected earnings further leading to positive association of stock returns and inflation. This is known as "earning channel". Second reason is Fischer effect or higher discount rates due to inflation leaving behind low share prices due to which negative relationship is observed. This is known as "discount rate channel".

As corporate earnings magnify with inflation in nominal terms, earning channel can be the source of protection for investors against unexpected inflation shocks. So through earning channel, in which a positive association of inflation and corporate earnings exist, equities can be useful hedge against inflation. Investors can protect themselves from inflationary pressure by purchasing common shares. Discussion of different studies reviewed in literature review revealed that focus of the studies was on capital gain. And equities were proven as effective 
hedge against inflation. In this study we are taking dividends as investor's return to examine the relationship of dividends with inflation and real growth rate.

\section{Methodology and Data Description}

\subsection{Data Description and Variables}

Study explores the long term causal relationship among dividend, inflation, real growth rate and earnings by using annual data for the period of 1966-2010. Taking a macroeconomic perspective, we do not focus on dividend payments of individual firms but aggregated dividend paid by non-financial companies listed on Karachi Stock Exchange. State Bank of Pakistan provides a hand book of statistics on the Balance Sheet Analysis of all non-financial companies listed on Karachi Stock Exchange. Data included in this analysis is the aggregate of all non-financial companies. Proxy used for Dividends is Dividend Yield (D.Y).

Data used is reliable because it is issued by the State Bank of Pakistan which is the central financial body collecting financial information of all companies. Current reference base period of Dividend Yield is 1966-2010.

\subsection{Inflation}

There is a common belief that the equity market can act as an effective hedge against inflation because stocks represent claims on real capital. Accepting this argument, inflation should lead to higher stock prices by increasing the nominal value of real capital.

Additionally, inflation magnifies the revenues of the corporate sector leading to higher earnings which in turn leads to an increase of stock prices. Taking this view, inflation should increase the dividend payments. Inflation is measured using annual inflation rates reported by State Bank of Pakistan. The current reference base period of Inflation is $1966-2010$.

\subsection{Return on Equity}

As dividends are paid from corporate earnings, study considered earnings of the non-financial companies. Increase in corporate earnings should increase the dividend payments. However, an increase in earnings is often not fully reflected in increase in dividends; one of the causes of this situation is dividend smoothening.

Taking macroeconomic perspective, individual companies are not the focus so aggregated earnings of all non-financial companies are considered. Return on Equity (ROE) is used as a proxy for earnings. Data period for ROE is $1966-2010$.

\subsection{Real Growth Rates}

Because of the fact that proponents of proxy hypothesis believe that there is relationship between inflation and real growth rate, we additionally included a measure of real economic activity in Pakistan as fourth variable namely Real GDP rates. An increase in real economic activity increases the corporate earnings of different sectors operating in the economy leading to higher earnings which may ultimately lead to higher dividend payments. Pakistan Bureau of Statistics provides data of Real GDP rates on annual basis. Data period taken for Real GDP rates is 1966-2010.

This study explores the long term causal relationship among dividend, inflation, real growth rate and earnings by using annual data for the period of 1966-2010. A general equation of the study is as follows;

$$
\text { D. } Y_{t}=\alpha_{0}+\alpha_{1} I N F_{t}+\alpha_{2} R O E_{t}+\alpha_{3} R G R_{t}+\mu_{t}
$$

Where:

$$
\begin{aligned}
& \text { DY = Dividend Yield; } \\
& I N F=\text { Inflation; } \\
& \text { ROE = Return on Equity; } \\
& \text { RGR = Real Growth Rates; } \\
& \mu_{t}=\text { Error term. }
\end{aligned}
$$

\section{Methodology}

There are number of methods available to test for the existence of long-run equilibrium relationship among time-series variables. Methods used for the purpose may include Engle and Granger (1987) test, fully modified OLS procedure of Phillips and Hansen's (1990), maximum likelihood base Johansen $(1988,1991)$ and JohansenJuselius (1990) tests. Requirement of these method is that variables in the system are of order one i.e. I (1). Moreover, these methods don't carry good small sample properties and suffer from low power. Due to these 
problems, a newly developed approach called autoregressive distributed lag (ARDL) approach to co-integration prposed by Pesaran and Shin (1999) is being used in recent years.

Justification to use this methodology in this study is due to its certain advantages over other co-integration procedures. For example, it can be used regardless of the stationary properties of the variables in the sample. Secondly, it helps in estimating the long-run estimates which are not possible in alternative co-integration approach. And finally, ARDL approach accommodates greater number of variables in comparison to other Vector Autoregressive (VAR) models.

Following steps are taken before applying ARDL approach;

- First of all stationarity of data is checked using Augmented Dicky Fuller test. It is used to check whether all variables are at level $(0)$ or at first difference.

$$
\Delta D Y_{t}=\beta 0+\sum \psi \mathrm{i} \Delta D Y_{t-i}+\sum \beta \mathrm{i} \Delta I N F_{t-i}+\sum \lambda \mathrm{i} \Delta R O E_{t-i}+\sum \delta \mathrm{i} \Delta R G R_{t-i}+\mu_{t}
$$

- In the second step, different diagnostics tests are applied to examine for serial correlation, normality, heteroscedesticity and functional form.

- When all the series are stationary at same level, J.J Approach of cointegration is applied, but when some series are stationary at levels and other at first or second differences, ARDL is widely used technique for this purpose.

ARDL approach to co-integration is applied in three stages.

Firstly, optimal lag length is chosen according to one of the standard criteria such as the Schwartz Bayesian or Akaike Information. After deciding the optimal lag length, ARDL equation is estimated according to the lag order selected. Following equation shows the ARDL representation of the model.

Secondly, after initial ARDL equation, error correction model is applied in to capture the short term as follows;

$$
\Delta D Y_{t}=\beta 0+\sum \beta \mathrm{i} \Delta I N F_{t-i}+\sum \lambda \mathrm{i} \Delta R O E_{t-i}+\sum \delta \mathrm{i} \Delta R G R_{t-i}+E C M+\mu_{t}
$$

Finally, stability of short-run and long-run coefficients is examined by employing cumulative sum (CUSUM) and cumulative sum of squares (CUSUMSQ) tests. If plots of CUSUM and CUSUMSQ statistics stay within the critical bonds of 5 percent level of significance then the null hypothesis (i.e., that the regression equation is correctly specified) cannot be rejected and model shows structure stability.

\section{Empirical Results}

\subsection{Unit Root Test}

Unit root test is used to check the stationarity of the data. We have used Augmented Dickey Fuller test to examine stationarity. Results of ADF statistics at intercept as well as on intercept and trend are shown in table 1. Results revealed that DY and INF are non-stationary at levels but at first difference they are stationary. ROE and RGR are stationary at levels.

Table 1. Augmented Dickey Fuller

\begin{tabular}{lllll}
\hline & Intercept & & \multicolumn{2}{l}{ Intercept \& Trend } \\
\hline Series & At Level & $1^{\text {st }}$ Difference & At level & $1^{\text {st }}$ Difference \\
DY & -2.73 & -9.08 & -3.19 & -8.99 \\
INF & -2.83 & -5.85 & -2.78 & -5.79 \\
ROE & -5.709 & -6.29 & -6.009 & -6.25 \\
RGR & -5.740886 & -9.56 & -5.716862 & -9.56 \\
1\% level & -3.596616 & -3.596616 & -4.192337 & -4.192337 \\
5\% level & -2.933158 & -2.933158 & -3.520787 & -3.520787 \\
$10 \%$ level & -2.604867 & -2.604867 & -3.191277 & -3.191277 \\
\hline
\end{tabular}

Different tests are applied to diagnose serial correlation, functional form and heteroscedasticity of data along with test of normality. Table 2 shows results of diagnostic tests. 


\subsection{Diagnostic Tests}

Table 2. Diagnostic tests

\begin{tabular}{lllc}
\hline Item & Test Applied & CHSQ $(\boldsymbol{\alpha} \mathbf{)}$ & Prob. \\
\hline Serial Correlation & LAGRANGE MULTIPLIER TEST & .3065 & .038 \\
Functional Form & RAMSEYS' RESET TEST & $.9193 \mathrm{E}-3$ & .976 \\
Normality & Test of Skewness and Kurtosis & 3.0474 & .218 \\
Heteroscedasticity & WHITE & .40219 & .516 \\
\hline
\end{tabular}

Table 2 shows that econometric problems like Heteroscedasticity and conflict to normal distribution has not been observed. Similarly, no model specification error exists with reference to functional form. However, the results indicate that there exists serial correlation. The ARDL model has been shown to be robust against residual autocorrelation. Therefore, the presence of autocorrelation does not affect the estimates, Laurenceson and Chai (2003).

When all the series are stationary at same level, J.J Approach of cointegration is applied, but when some series are stationary at level and other at first or second difference, ARDL is widely used technique for this purpose. As results of Augmented Dickey Fuller revealed that series are stationary at different levels, this study adapts ARDL approach to examine the long term relationship between Dividend Yield, Return on Equity, Inflation and Real Growth Rates.

\subsection{ARDL Approach}

\subsubsection{Selecting the Lag Order}

Different criteria for selection of Lag order are available. Most widely used are Akaike Information Criterion (AIC), Schwarz Bayesian Criterion (SBC) and Hannan-Quinn Information Criterion. Maximum Lag length is decided as 1 using SBC. Table 3 exhibits results of ARDL Model based on Schwarz Bayesian Criterion.

Table 3. ARDL estimates based on Schwarz Bayesian criterion

\begin{tabular}{lllll}
\hline Dependent variable is DY & & & & \\
\hline Regressor & Coefficient & Standard Error & T-Ratio & Prob. \\
DY(-1) & 0.77639 & 0.09964 & 7.7919 & .000 \\
ROE & -0.010111 & 0.047412 & -.21325 & .832 \\
INF & 0.10735 & 0.045211 & $2.3745]$ & .023 \\
RGR & 0.062778 & 0.135 & .46501 & .645 \\
\hline
\end{tabular}

Results reveal that one lag of dividend yield and inflation has significant positive relationship with dividend yields. While Return on equity and real growth rates have insignificant relationship with dividend yields.

Table 4. Statistics

\begin{tabular}{ll}
\hline R-Squared & .49410 \\
\hline R-Bar-Squared & 45.518 \\
F-stat & 12.6967 \\
Prob. F-stat & .000 \\
Akaike Info. Criterion & -89.5330 \\
Schwarz Bayesian Criterion & -93.0554 \\
DW-statistic & 2.4957 \\
\hline
\end{tabular}

The results of the bounds testing approach for Co-integration in table 4 show that the calculated F-statistic is 12.69 at 0 percent level of significance implying that the null hypothesis of no co-integration cannot be accepted and there exists co-integration relationship among the variables in this model. The value of R-Bar-Squared is 49.5 percent which indicates a good degree of correlation among variables. F statistics is also significant at $0 \%$ which indicates overall goodness of fit. 


\subsubsection{Long-Run Coefficients}

Table 5. Estimated long run coefficients for selected ARDL model

\begin{tabular}{lllll}
\hline Regressor & Coefficient & Standard Error & T-Ratio & Prob. \\
\hline ROE & -0.04522 & 0.21845 & -.20699 & .837 \\
INF & 0.48009 & 0.24622 & 1.9498 & .058 \\
RGR & 0.28075 & 0.57699 & .48658 & .629 \\
\hline
\end{tabular}

Table 5 displays the results of long term coefficients under ARDL Approach. Results reveal that ROE and real growth rates have insignificant long run relationship with dividend yield. Inflation has long run positive relationship with dividend yield.

\subsubsection{Error Correction Mechanism}

Table 6. Error correction representation for the selected ARDL model

\begin{tabular}{lllll}
\hline Regressor & Coefficient & Standard Error & T-Ratio & Prob \\
\hline dROE & -0.010111 & 0.047412 & -0.21325 & .832 \\
dINF & 0.10735 & 0.045211 & 2.3745 & .023 \\
dRGR & 0.062778 & 0.135 & 0.46501 & .645 \\
ecm $(-1)$ & -0.22361 & 0.09964 & -2.2442 & .03 \\
\hline
\end{tabular}

$$
\mathrm{ECM}=\mathrm{DY}+.045216 * \mathrm{ROE}-.48009 * \mathrm{INF}-.28075 * \mathrm{RGR}
$$

Error correction results reveal that real growth rate and return on equity have statistically insignificant relation with dividends in short run. Inflation has statistically significant positive relationship with dividend yields.

The coefficient of determination $\left(\mathrm{R}^{2}\right)$ after error correction mechanism is $17.6 \%$, which shows significant fitness of the data, the adjusted $\mathrm{R}^{2}$ is at $11.31 \%$. Durbin Watson value is 2.49 which show no Autocorrelation among the variables. F-statistic is 12.69 and significant showing a good fit of the model. It is shown in table below.

Table 7. Statistics

\begin{tabular}{ll}
\hline R-Squared & .17650 \\
\hline R-Bar-Squared & .11315 \\
F-stat & 12.6967 \\
Prob. F-stat & .000 \\
Akaike Info. Criterion & -89.5330 \\
Schwarz Bayesian Criterion & -93.0554 \\
DW-statistic & 2.4957 \\
\hline
\end{tabular}

ECM (-1) is one period lag value of error terms that are obtained from the long-run relationship. The coefficient of ECM (-1) indicates how much of the disequilibrium in the short-run will be fixed (eliminated) in the long run. As expected, the error correction variable ECM (-1) has been found negative and also statistically significant. The Coefficient of the ECM term suggests that adjustment process is quite fast and $22.36 \%$ of the previous period's disequilibrium in dividends from its equilibrium path will be corrected in the current period.

\section{CUSUM and CUSUMSQ Statistics}

CUSUM and CUSUMSQ plots are drawn to check the stability of short run and long run coefficients in the ARDL error correction model. Figure 1 shows the cumulative sum of recursive residuals whereas Fig 2 displays the cumulative sum of squares of recursive residuals. 


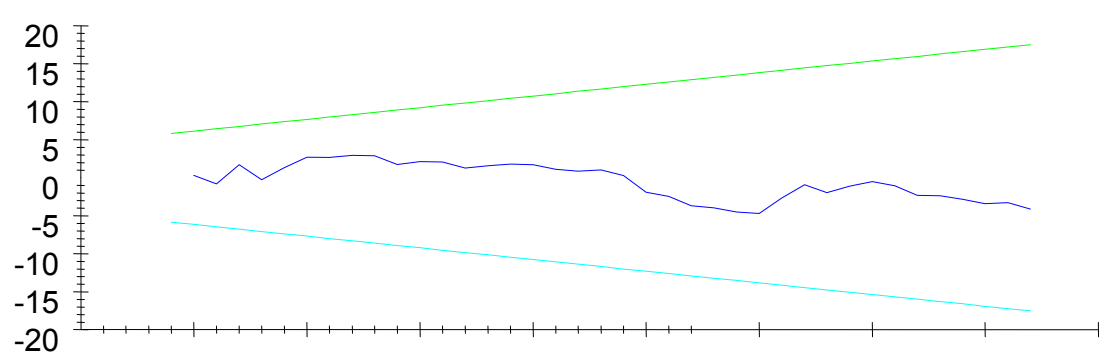

The straight lines represent critical bounds at $5 \%$ significance level

Figure 1. Plot of cumulative sum of recursive residuals

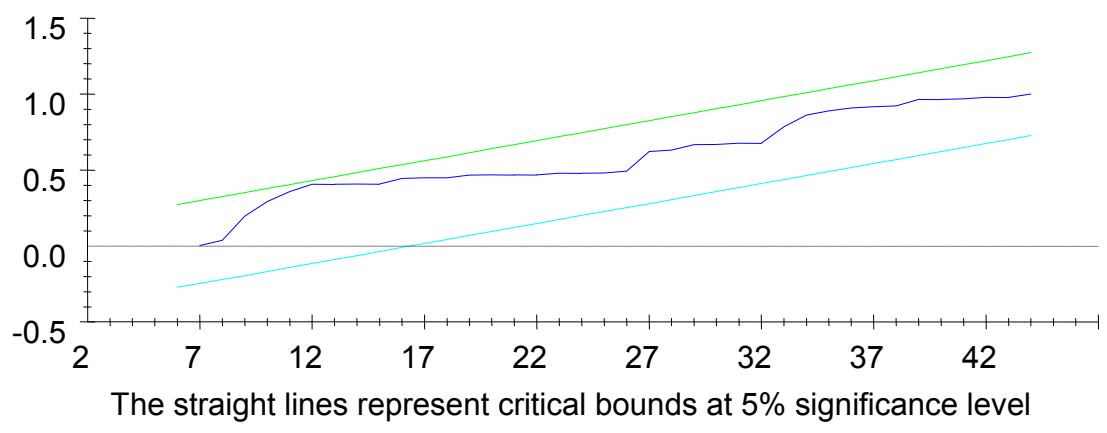

Figure 2. Plot of cumulative sum of squares of recursive residuals

Figure 1 and 2 show that both CUSUM and CUSUMSQ are within the critical bounds of $5 \%$ so it indicates that the model is structurally stable.

\section{Conclusion}

Study established the existence of positive relationship between dividend and inflation which is consistent with the findings of Basse (2009) and Basse and Reddemann, (2011). Inflation is significant in both long term and short term. This positive association can be justified in two ways; one is as inflation affects revenues and variable cost not the fixed cost, it simply increases the nominal volume of corporate earnings and therefore dividend payouts, secondly, management feels that there is some optimal dividend policy. Consequently, there may be an incentive to maintain the real value of dividend income.

Return on equity showed no relationship with dividend yield. It could be due to the reason that companies have a dividend policy and pay dividends irrespective of the growth in earnings and other factors. So companies pay dividends to meet market expectation that could be the one of the reasons.

Real growth rates have no effect on dividends. Supply-side models assume that GDP growth of the underlying economy transforms to shareholders in two forms. Firstly, it flows into corporate earnings and earnings per share (EPS) growth, and secondly growth in EPS translates into equity price increases. Companies are then justified to retain profits as shareholders experience capital value gains and don't insist in cash dividends. Another possible explanation of this effect may be the implication of pecking order theory that companies prefer to use internal equity during the period of growth. Companies may retain large chunk of their earnings and may not increase the amount of dividends.

Study invites additional research for further insight. Many other major macroeconomic factors specifically monetary policy can be used along with these variables. Although, Pandey and Bhat, (2007) in India and Mohsin 
and Ashraf (2011) in Pakistan studied the monetary policy restrictions on dividends, their work used only single variable as monetary policy restriction. It would be interesting to analyze the dividends with various other macroeconomic variables.

\section{References}

Amihud, Y. (1996). Unexpected inflation and stock returns revisited--evidence from Israel. Journal of Money, Credit and Banking, 22-33. http://dx.doi.org/10.2307/2077964

Baker, H. K., \& Powell, G. E. (1999). How corporate managers view dividend policy. Quarterly Journal of Business and Economics, 17-35.

Baker, H. K., Farrelly, G. E., \& Edelman, R. B. (1985). A survey of management views on dividend policy. Financial Management, 78-84. http://dx.doi.org/10.2307/3665062

Barro, R. J. (1995). Inflation and economic growth (No. w5326). National bureau of economic research.

Basse, T. (2009). Dividend policy and inflation in Australia: results from cointegration tests. International Journal of Business and Management, 4(6), 13. http://dx.doi.org/10.5539/ijbm.v4n6p13

Basse, T., \& Reddemann, S. (2011). Inflation and the dividend policy of US firms. Managerial Finance, 37(1), 34-46. http://dx.doi.org/10.1108/03074351111092139

Black, F. (1976). The dividend puzzle. The Journal of Portfolio Management, 2(2), 5-8. http://dx.doi.org/10.3905/jpm.1976.408558

Black, F., \& Scholes, M. (1974). The effects of dividend yield and dividend policy on common stock prices and returns. Journal of Financial Economics, 1(1), 1-22. http://dx.doi.org/10.1016/0304-405X(74)90006-3

Bodie, Z. (1976). Common stocks as a hedge against inflation. The Journal of Finance, 31(2), 459-470. http://dx.doi.org/10.1111/j.1540-6261.1976.tb01899.x

Brandt, M. W., \& Wang, K. Q. (2003). Time-varying risk aversion and unexpected inflation. Journal of Monetary Economics, 50(7), 1457-1498. http://dx.doi.org/10.1016/j.jmoneco.2003.08.001

Campbell, J. Y., \& Shiller, R. J. (1988). Stock prices, earnings, and expected dividends. The Journal of Finance, 43(3), 661-676. http://dx.doi.org/10.1111/j.1540-6261.1988.tb04598.x

Collins, M. C., Saxena, A. K., \& Wansley, J. W. (1996). The role of insiders and dividend policy: a comparison of regulated and unregulated firms. Journal of Financial and Strategic Decisions, 9(2), 1-9.

Engsted, T., \& Tanggaard, C. (2002). The relation between asset returns and inflation at short and long horizons. Journal of International Financial Markets, Institutions and Money, 12(2), 101-118. http://dx.doi.org/10.1016/S1042-4431(01)00052-X

Fama, E. F. (1981). Stock returns, real activity, inflation, and money. The American Economic Review, 545-565.

Fama, E. F., \& Schwert, G. W. (1977). Asset returns and inflation. Journal of financial economics, 5(2), 115-146. http://dx.doi.org/10.1016/0304-405X(77)90014-9

Feldstein, M. S. (1982). Domestic saving and international capital movements in the long run and the short run.

Fischer, G. (2013). Investment choice and inflation uncertainty.

Geske, R., \& Roll, R. (1983). The fiscal and monetary linkage between stock returns and inflation. The Journal of Finance, 38(1), 1-33. http://dx.doi.org/10.1111/j.1540-6261.1983.tb03623.x

Gultekin, N. B. (1983). Stock market returns and inflation: evidence from other countries. The Journal of Finance, 38(1), 49-65. http://dx.doi.org/10.1111/j.1540-6261.1983.tb03625.x

Jensen, M. C., \& Meckling, W. H. (1979). Theory of the firm: Managerial behavior, agency costs, and ownership structure (pp. 163-231). Springer Netherlands.

Kaleem, A., \& Salahuddin, C. (2006). Impact of dividend announcement on common stock prices at Lahore Stock Exchange (Pakistan). South Asian Journal of Management, 13(2).

Kolari, J. W., \& Anari, A. (2001). Stock prices and inflation. Journal of Financial Research, 24(4).

Laurenceson, J., \& Chai, C. H. (2003). Financial reform and economic development in China. Edward Elgar Publishing.

Luintel, K. B., \& Paudyal, K. (2006). Are common stocks a hedge against inflation? Journal of Financial Research, 29(1), 1-19. http://dx.doi.org/10.1111/j.1475-6803.2006.00163.x 
Miller, M. H., \& Modigliani, F. (1961). Dividend policy, growth, and the valuation of shares. The Journal of Business, 34(4), 411-433. http://dx.doi.org/10.1086/294442

Miller, M. H., \& Scholes, M. S. (1978). Dividends and taxes. Journal of Financial Economics, 6(4), 333-364. http://dx.doi.org/10.1016/0304-405X(78)90009-0

Miller, M. H., \& Scholes, M. S. (1982). Dividends and taxes: Some empirical evidence. The Journal of Political Economy, 1118-1141. http://dx.doi.org/10.1086/261114

Modigliani, F., \& Cohn, R. A. (1979). Inflation, rational valuation and the market. Financial Analysts Journal, 24-44. http://dx.doi.org/10.2469/faj.v35.n2.24

Mohsin, H. M., \& Ashraf, M. S. (2011). Monetary policy restriction and dividend behavior of Pakistani firms: an empirical analysis.

Pandey, I. M., \& Bhat, R. (2007). Dividend behaviour of Indian companies under monetary policy restrictions. Managerial Finance, 33(1), 14-25. http://dx.doi.org/10.1108/03074350710715782

Partington, G. H. (1985). Dividend policy and its relationship to investment and financing policies: empirical evidence. Journal of Business Finance \& Accounting, 12(4), 531-542. http://dx.doi.org/10.1111/j.1468-5957.1985.tb00792.x

Pesaran, M. H., Shin, Y., \& Smith, R. P. (1999). Pooled mean group estimation of dynamic heterogeneous panels. Journal of the American Statistical Association, 94(446), 621-634. http://dx.doi.org/10.1080/01621459.1999.10474156

Schwert, G. W. (1981). The adjustment of stock prices to information about inflation. The Journal of Finance, 36(1), 15-29. http://dx.doi.org/10.1111/j.1540-6261.1981.tb03531.x

\section{Copyrights}

Copyright for this article is retained by the author(s), with first publication rights granted to the journal.

This is an open-access article distributed under the terms and conditions of the Creative Commons Attribution license (http://creativecommons.org/licenses/by/3.0/). 